\title{
Indonesian Vocabulary Learning for Early Childhood Using Paper Puppet Media
}

\author{
Reni Nurapriani, Revita Yanuarsari, Agus Ruswandi, Hendi Suhendraya Muchtar, Luki \\ Luqmanul Hakim, \\ \{reni.nurapriani@fkip-uninus.ac.id, revita@uninus.ac.id, agus.ruswandi@fkip-uninus.ac.id, \\ hendi@uninus.ac.id, luqmanhakim@uninus.ac.id\} \\ Universitas Islam Nusantara, Bandung, Indonesia ${ }^{1}$
}

\begin{abstract}
Vocabulary is important for developing language competence for children. Teachers should develop children's vocabulary skills for communicating well. Stimulus is necessary for optimal developing the children language skill. Among the teacher's efforts to develop children's words is to use 'wayang kertas'. 'Wayang kertas' is a medium made by students through drawing and cutting pictures made by students, then for vocabulary learning media. Based on the results, 'wayang kertas' media has proven to be able to develop the children language abilities.Based on the results of the classroom implementation, the paper puppet media has been proven to be able to develop early childhood vocabulary skills.
\end{abstract}

Keywords: Early, chilhood, vocabulary, paper, puppet.

\section{Introduction}

An important factor that has a big influence on the success of students' learning is teachers' creativity. Mulyasa said that the 2013 character and competency based curriculum, teachers wanted to change the pattern of education from orientation to results and material to education as a process [1]. In this case, towards the preparation of the 2013 curriculum, students need the teachers' creativity to be a facilitator and learning partner. The teacher is not only to share information to students, but also to be creative in providing services and ease of learning (facilitating learning) to all students, so that they can learn in a fun atmosphere, full of enthusiasm, not anxious and dare to express opinions. One form of teacher creativity is used of media to help convey the subject matter so that it can be well comprehended by students.

The other important components in the teaching and learning process is learning media. Learning can also be easily understood by students with learning media. Media is also a tangible manifestation in terms of the teacher's creativity in teaching. The media which used in the research is 'wayang kertas'. 'wayang kertas' is one of the visual learning media in the form of character figures that will be played by students. 'Wayang Kertas' that intended in this study is concept of favorite cartoon characters of students.

The use of more educative teaching aids in Early Childhood learning can further enable students in learning, so that learning activity become more meaningful; and (2) the use of educative teaching aids can awaken the reflection ability of Early Childhood on the concepts and relationships under study[2].Educational teaching aids aresomething that can be used 
asfacilities or equipment for playing thatcontains the value of educationand can develop the wholechildren's ability[3].

In language learning, there are listening, speaking, reading and writing skill which found in the language skill. These four skills relates between one another.

Three-year-olds have around 900 to 1000 words and about $90 \%$ of what they say can be understood. They can easily produce three-word sentences. Language becomes the main mechanism in making their needs, feelings, and thoughts known to others. Children of this aged begin to understand and respond to many questions from the people around them. Children at this age begin to use well-arranged sentences according to the rules of grammar. They begin to use personal pronouns correctly [4]

At the age of 5 and 6 years, the sentence of the child consists of six to eight words. They also have been able to explain the meaning of simple words, knowing the antonym word. They can also use conjunctions, prepositions and articles. Language of children aged five and six years develop continuously. Seefeld says that their vocabulary extends to 5,000 to 8,000 words [4].

From the first observation at Mekar Arum Kindergarten, data was shown that the teachers had not used a learning media and still used conventional teaching methods. As a result students will experience difficulties in terms of capturing the contents of the subject matter and can allow the occurrence of wrong or different interpretations or perceptions from teacher to student. Therefore an instructional media innovation is needed to increase student activity and learning outcomes.

Learning media, according to Kemp and Dayton [5], can fulfill three main functions if the media is used for individuals, groups, or groups of listeners that are large in number, there are (1) motivating interests or actions, (2) presenting information, and (3) giving instructions. To fulfill the motivational function, learning media can be realized through drama or entertainment techniques. The expected outcome is to generate interest and stimulate students or listeners to act. Achieving this goal will affect attitudes, values, and emotions.

Basically vocabularies' comprehension is one component of language learning. Vocabulary is very important for children. With the previous explanation, it can be seen that vocabulary in children is very important because the language itself is a device for communicating. In early childhood language development is very important, because early childhood is a sensitive period for children. When making initial observations found $75 \%$ or 12 students who have a low Indonesian vocabulary or not in accordance with the indicators. While $25 \%$ or 4 students who have Indonesian vocabulary are good or in accordance with the indicators. The low Indonesians' vocabulary of children can be caused by parents which communicate with their children more often using mother tongue (Sundanese) and Indonesian is very rarely used when communicating with children.

Actually, parents are very influential on the development of children's vocabulary. Because children are imitators, they will imitate what they see and hear from their parents. Often parents communicate with children using Javanese and parents also often say less well in front of children, so children imitate what their parents said. In this case the child does not get the Indonesian vocabulary teaching from parents, so that the Indonesian vocabulary mastery that is owned by the child does not develop optimally, besides that the environment around the child also influences the child's Indonesian vocabulary mastery.

One area of development in the growth of basic skills in Early Childhood Education is the development of language. Language allows children to translate experiences into symbols that can be used to communicate and think. Children get language skills from birth to age 6 , he 
never learns language, especially vocabulary specifically. However, at the end of the early age the average child has saved more than 14,000 vocabulary [6].

In subsequent developments, children are able to add vocabulary independently in the form of good communication. Montessori states that, when children "learn" language through interaction with adults, children do not just "learn" editorial words and sentences, but also the structure of the word and sentence itself.[6] Language is an important aspect of development in infancy and childhood. Through language, children communicate with the primary environment, there are mothers, parents, and people at home and the wider environment.

From the description above it can be concluded that language development in early childhood is a change in the sound symbol system that affects the ability to speak of early childhood. With the ability to speak, early childhood can identify themselves, and interact and work with others.

Among the ways to improve vocabulary skills for early childhood is to use effective media. Among the learning media that can be used are paper puppet media. Media of wayang kerta is a learning media created by students through drawing, coloring, cutting, and then being used as a media for "puppet paper" for learning Indonesian vocabulary with themes about family.

As for the example of the wayang media referred to as in the following picture:

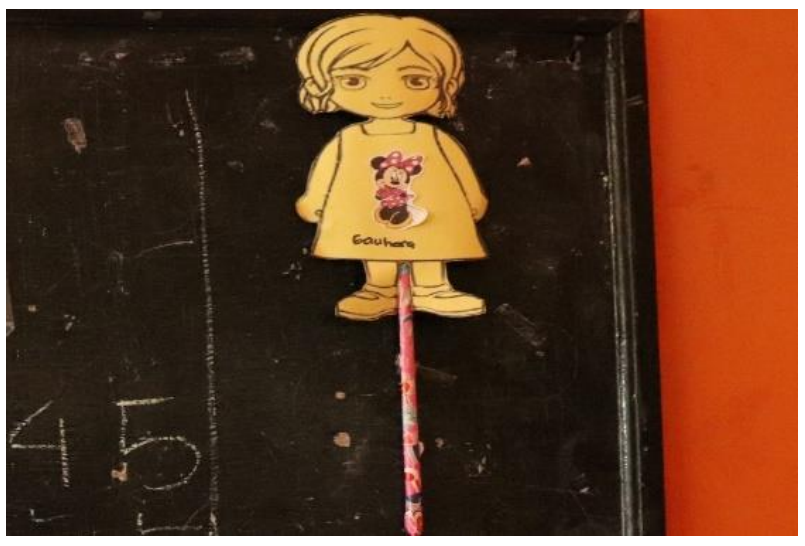

Fig. 1. Paper Puppets Childern Made

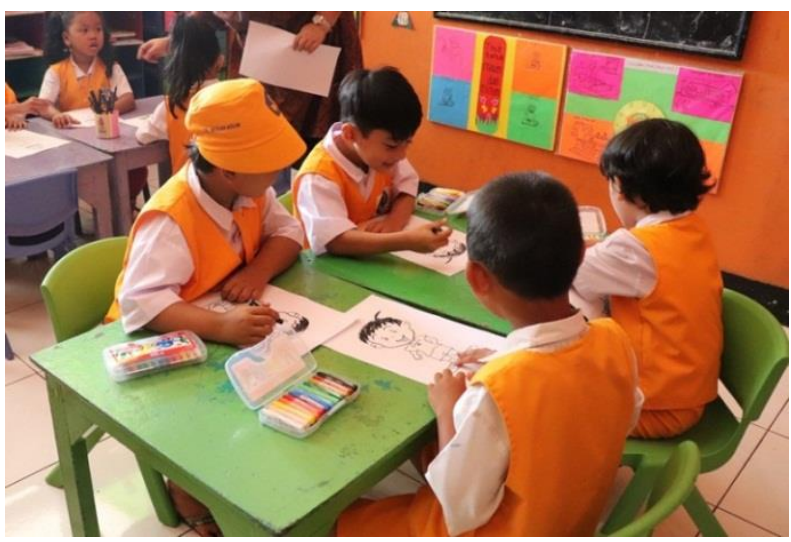

Fig. 2.The Child Made a Puppet Paper Together 
Based on the eplanation above, we have state of this research objectives to explain step on procedur of Indonesian vocabulary learning by using the puppet paper media ini Mekar Arum kindergarten.Other than that, the objective this research to explain that the puppet paper media can improving ability of children in Indonesia vocabulary learning.

\section{Method}

Classroom Action Research is a method of finding out what works best in your own classroom so that you can improve student learning [7]. This research type of research used is classroom action research, which is research that aims to contribute significantly to improving teacher professionalism, preparing knowledge, understanding and insight into the behavior of teaching teachers and students learning. The approach taken is a qualitative approach, because in taking action to the research subject is preferred is to reveal the meaning of the meaning and learning process as an effort to increase motivation, excitement and learning achievement through actions taken as stated by Bogdan and Bikien [8]. The nature of action research conducted is participatory collaborative, namely collaboration between researchers and practitioners in the field.

Classroom action research is a systematic study of efforts to improve the implementation of educational practices by a group of teachers by taking actions in learning, based on their reflection on the results of these actions [9]. Action research is the application of fact discovery to problem solving in social situations with a view to improving the quality of actions carried out in it, which involve collaboration and collaboration between researchers, practitioners, and lay people [10].

The subject of this research was 13 students of Mekar Arum Bandung Indonesia kindergarten as many as 13 students. Data collection techniques in this study use observation, interview and documentation techniques. Data analysis techniques used in this study are data reduction, data display, and data verification of research results.

\section{Result and Discussion}

\subsection{Planning}

The atmosphere of learning more interesting by holding the game first so that the children are more enthusiastic, such as the "Applause" game will train motoric and cognitive children.

Daily learning plan in accordance with the theme at the time was still the Universe but learning to use the singing method. And before learning begins, children are given rules, that is, if they are orderly during learning, get a gift from the teacher.

Before the learning begins, the teacher and researcher provide real examples of what will be learned. At meetings 1 and 2 the teacher gave examples of songs along with expressions that matched the contents of the song.

Each vocabulary meeting that will be studied is written in writing and spelled one by one. At the first vocabulary meeting that was studied, it was about the song "Bintang Kecil" and at the second meeting the learned vocabulary was about the song "Ambilkan Bulan Bu". 
Research instruments is form of song lyrics, observation sheets to assess children's activity and a sheet of assessment of Indonesian children's vocabulary mastery.

\subsection{Implementation}

Based on the results of observations regarding the implementation of research actions which are divided into 2 (two) cycles, as well as the final results of the data that has been collected in order to improve vocabulary in children of group A TK Mekar Arum, through paper puppet media conducted by researchers and colleagues. Researchers provide action to children through 'wayang kertas' media first researchers measure the child's initial ability to increase vocabulary. This is done to find out how the level of ability to achieve children's language development in increasing vocabulary before using 'wayang kertas' media. Based on the results of pre-action observations (preliminary studies), the researchers attempt to overcome the problems that arise by conducting research actions through learning activities using 'wayang kertas' media, as an effort to provide an increase in children's vocabulary through 'wayang kertas' which began with the cycle I.

\section{Cycle I}

Puppet media can used as an alternative media learning in elementary school. Media learning is useful for more learning interesting and the atmosphere of learning becomes more fun [11].

Classroom action research is carried out in 2 (two) cycles (four meetings) which are implemented in (4 stages), consisting of planning, implementing / acting, observing actions and reflecting actions. In this learning the development of learning tools that are used to support the success of teaching and learning activities is the daily learning plan prepared earlier. The daily learning plan used consists of initial activities, core activities, rest, final activities.

The implementation of learning activities for cycle I in meeting 1 on Monday is grouped A TK Mekar Arum with a total of 13 children consisting of 8 boys and 5 girls. At the first meeting the researchers prepared 2 pieces of 'wayang kertas' media, which corresponded to their respective characters, then at this meeting, the teacher told the story "Sabar menunggu giliran", this was done to find out how much the impact of the 'wayang kertas' media application on children's vocabulary abilities when compared to other media such as the story book media that has been used by the Mekar Arum kindergarten teacher for storytelling activities.

The second meeting in the first cycle was held on Wednesday which focused on the indicators mentioning the bad traits of the characters in the story. At this second meeting, the teacher added wayang media so that it was more interesting with the 'wayang' order plastered in the banana tray, and changed the title of the story that was more interesting to the child, with the title "Saya tidak marah lagi". Although with the same 'wayang', but for this the teacher conditions the condition of the child to be more relaxed and interested in the way the story is delivered by the researcher.

As for the results of class actions in the first cycle as in the following table: 
Table 1. Indonesian Vocabulary Ability in Cycle I

\begin{tabular}{lcccc}
\hline \multicolumn{1}{c}{ Ability } & Poor & Percentage (\%) \\
& & & $\begin{array}{c}\text { Verry } \\
\text { Good }\end{array}$ & Excellent \\
\hline $\begin{array}{l}\text { Mentioning Vocabulary } \\
\text { about Family Members }\end{array}$ & 30.77 & 46.15 & 23.08 & 0 \\
Repeat vocabulary & 23.08 & 30.77 & 46.15 & 0 \\
Tells about Family & 23.08 & 38.46 & 38.46 & 0 \\
AVERAGE & 25.64 & 38.46 & 35.90 & 0 \\
\hline
\end{tabular}

Based on the table above, it can be seen that the ability of students in "Mentioning Vocabulary about Family Members" the "poor" abilities were as much as $30.77 \%$, the "good" ability in the category was around $46.15 \%$, while the "very Good" abilities included were as good as $23.08 \%$. On the ability "Repeating Vocabulary" is known that the "poor" ability is lacking as much as $23.08 \%$, the "good" ability is as much as $30.77 \%$ and the "very good" ability as much as $46.15 \%$. In the indicator "Retelling the Family" which is included in the category of "poor" as much as $23.08 \%$, while the category "Good" as much as $38.46 \%$ and the ability of "Very Good" as much as $38.48 \%$. Based on these results, the researchers conclude that there needs to be research for the next action.

\section{Cycle II}

The implementation of cycle 2 is aimed to overcome the obstacles in cycle 1 and improve the learning process so that the problems that arise can interact well, so it can improve children's vocabulary abilities optimally. Just like in the first cycle, this second cycle consists of 4 (stages) consisting of planning, implementing, observing and reflecting.

At the first meeting held on Monday in a group A TK Mekar Arum with 20 children consisting of 12 boys and 8 girls, the teacher prepared 3 'wayang kertas' media, the three 'wayang' media will help the teacher in carrying out the cycle II with a more interesting story for children, which is intended to improve the development of children's vocabulary skills. At the first meeting in the second cycle, the teacher conducted a storytelling activity entitled "Ke sekolah tepat waktu".

And the second learning and teaching of the second cycle was held on Wednesday. Based on observations at the 1st meeting that showed the child did not understand the contents of the story, the teacher tried to add more 'wayang' media, it will help the teacher in bringing a story that is more interesting to children, namely the title "Hari pertama masuk sekolah".

During the learning process takes place the teacher and collaborator assesses observations on children's activities and the level of achievement of vocabulary development in the children of group A TK Mekar Arum by using the preservation prepared by the teacher in the form of questions and answers conducted during learning.

From the results of observations of the learning process in the second cycle of this second meeting, improvements in teaching patterns and changes in improving children's vocabulary through storytelling methods using 'wayang' media reached $85 \%$ of 20 children. 
Thus, it can be concluded that the quality of the second cycle research action is in line with expectations, so it does not require repetition in the next cycle.

As for the results of class actions in the second cycle as in the following table:

Table 2. Indonesian Vocabulary Ability in Cycle II

\begin{tabular}{|c|c|c|c|c|}
\hline \multirow[b]{2}{*}{ Ability } & \multicolumn{4}{|c|}{ Percentage (\%) } \\
\hline & Poor & Good & $\begin{array}{l}\text { Verry } \\
\text { Good }\end{array}$ & Excellent \\
\hline $\begin{array}{l}\text { Mentioning Vocabulary } \\
\text { about Family Members }\end{array}$ & 0 & 0 & 30.77 & 69.23 \\
\hline Repeat vocabulary & 0 & 0 & 46.15 & 53.85 \\
\hline Tells about Family & 0 & 0 & 38.46 & 61.54 \\
\hline AVERAGE & 0 & 0 & 38.46 & 61.54 \\
\hline
\end{tabular}

Based on the table above, it can be seen that the ability of students in "Mentioning Vocabulary about Family Members" the "very good" abilities were as much as $30.77 \%$, the "excellent" ability in the category was around 69,23\%. On the ability "Repeating Vocabulary" is known that the "very good" ability is lacking as much as $46,15 \%$, the "excellent" ability is as much as $53,85 \%$. In the indicator "Retelling the Family" which is included in the category of "very good" as much as $38,46 \%$, while the category "excellent" as much as $61,54 \%$. Based on these results, the researchers concluded that this class action research was enough to reach cycle II.

This result, can we take the model to improving ability vocabulary learning of student. We can comparating with the research by Rebbeca Among these classrooms were 3 mainstream, 1 two-way bilingual, and 1 structured immersion classroom. The classrooms served 44 English-only (EO) and 28 English-language-learning (ELL) children. Linear growth analyses investigated children's learning of taught words, as assessed by a researcher-designed vocabulary measure, and their overall growth in vocabulary knowledge, measured by the Test of Language Development Primary:3. Findings showed that ELLs learned target words at the same rate, and grew in general vocabulary at a faster rate, than Eos[12].

\section{Conclusion}

Based on the results and discussions, can be drawn conclusionsthat Indonesian vocabulary learning for early childhood by using "puppet paper" media becomes more active, efficient and student-centered. Students learn to be more fun.Paper puppet media can develop vocabulary skills for early childhood to be better. In the first cycle the average ability of each indicator in the ability of "less" as much as $25.64 \%$, the ability of "enough" as much as $38.46 \%$ and the ability of "good" as much as $35.90 \%$. In the second cycle the average ability of each indicator in the "Good" ability was $38.46 \%$, the ability was "Very Good" as much as $61.54 \%$ and there were no students' abilities in the poor category and enough categories. This shows that students' ability to develop Indonesian vocabulary can develop through learning using paper puppets 


\section{References}

[1] E. Mulyasa, Pengembangan Dan Implentasi Pemikiran Kurikulum. Bandung: Remaja Rosdakarya, 2013.

[2] L. L. Hakim and R. Yanuarsari, "Use of Educative Teaching Aids in Improving LogicalMathematical Intelligence for Early Childhood," in Ahmad Dahlan International Conference on Mathematics and Mathematics Education, 2018, vol. 1, pp. 32-37.

[3] Y. L. Sulastri, A. Rahma, and L. L. Hakim, "IbM Pembuatan Alat Permainan Edukatif (APE) Ramah Anak Bagi Guru Paud di Kota Bandung,” J. Pengabdi. Kpd. Masy., vol. 7, no. 2, pp. 84$91,2017$.

[4] C. Seefedelt and B. A. Wasik, Pendidikan Anak Usia dini. Menyiapkan Anak Usia Tiga, Empat, Lima Tahun Masuk Sekolah. Jakarta: Indeks, 2008.

[5] K. J.E and D. K. Dayton, Planning and Producing Intructional Media. New York: Harper \& Row Publisher, 1985.

[6] Suyadi, Psikologi Belajar Anak Usia Dini. Yogyakarta: Pedagogia, 2010.

[7] G. Mettetal, "The what, why and how of classroom action research," J. Scholarsh. Teach. Learn., pp. 6-13, 2002.

[8] B. RC and B. SK, Qualitative research for education to theory and methods. Boston: Allyin and Bacon, inc, 2003.

[9] D. Hopkins, A Teacher's Guide to Classroom Research. Philadelphia: Open University Press, 1993.

[10] A. Burns, Collaborative Action Research for English Language. Teachers. United Kingdom: Cambridge University, 1999.

[11] H. Zafira and F. P. Artharina, "Pengembangan Media Wayang Tematik Pada Tema Indahnya Negeriku Sebagai Pendukung Scientific Approach Kelas IV Sekolah Dasar," Refleks. edukatika, vol. 8, no. 1, 2017.

[12] R. D. Silverman, "Vocabulary development of English-language and English-only learners in kindergarten," Elem. Sch. J., vol. 107, no. 4, pp. 365-383, 2007. 